\title{
Tuning the chords of youth identity: A Community-Based Project focused on music in English'
}

\section{Afinando los acordes de la identidad juvenil: Un proyecto de comunidad enfocado en la música en Inglés.}

\author{
Edna Mercedes Bonilla-Salazar ${ }^{2 *}$ \\ Universidad del Tolima, Colombia
}

\begin{abstract}
This is an exploratory case study implemented in a public school of Ibagué Colombia, that reports findings of a qualitative research. In this study tenth graders EFL students, explored into their local contexts, salient aspects of youth identity, that emerged from interaction with music in English. The study is framed on some basic principles of Critical Pedagogy (CP) and foundations of Community- Based Pedagogies (CBP). Content data analysis was used to examine the information obtained from the different tools of data collection: community mapping, questionnaires, recorded semi-structured interviews and notes in the teacher's journal. Finally, member checking was implemented to validate data and to increase the credibility and validity of this qualitative study. Conclusions and pedagogical implications reveal how local inquiries focused on music in English become a source for language learning and enlighten curriculum designers and teachers towards the construction of a flexible curriculum with relevant content, oriented to youth identity exploration and understanding.
\end{abstract}

Key words: Identity; Community based pedagogy (CBP); Critical Pedagogy (CP); music as a pedagogical tool.

\section{Resumen}

Este es un estudio exploratorio de caso implementado en un colegio público de Ibagué Colombia, que reporta los hallazgos de una investigación cualitativa. Para esta 48 investigación, estudiantes de décimo grado de Inglés como lengua extranjera, exploran en sus contextos locales, aspectos sobresalientes en la identidad juvenil, que surgen a partir de la interacción permanente con la música en Inglés. El estudio está enmarcado en algunos principios básicos la teoría de Pedagogía Crítica y fundamentos de la

1 Received: February 22nd 2018/ Accepted: May 3rd 2019

2 embonillas@ut.edu.co 
Pedagogía Basada en la Comunidad. El análisis de contenido de datos fue usado para examinar la información de las diferentes herramientas de recolección de datos: mapeo de la comunidad, cuestionarios, entrevistas semi- estructuradas grabadas en video y diario de campo del docente. Finalmente, la revisión de los hallazgos por parte de los participantes fue implementada para validar los datos e incrementar la validez de este estudio cualitativo. Las conclusiones y las implicaciones pedagógicas revelan cómo las indagaciones locales enfocadas en la música en Inglés, se convierten en un recurso para la enseñanza del idioma y a su vez ilustran a diseñadores del currículo y docentes, en cuanto a la construcción de un currículo flexible, con contenido relevante orientado a la exploración y comprensión de la identidad juvenil.

Palabras clave: Identidad; Pedagogía basada en la comunidad; Pedagogía Crítica; Música como herramienta pedagógica.

\section{Resumo}

Este é um reconto de uma experiência pedagógica através de um estudo de caso, implementado em uma instituição pública de Ibagué, Colômbia, que reporta as descobertas de uma pesquisa qualitativa realizada com estudantes de $2^{\circ}$ ano de ensino médio e alguns participantes das comunidades próximas ao colégio. O projeto visualiza alguns construtos de Pedagogia Crítica tendo em vista princípios de Metodologia Baseada na Comunidade. Os dados foram coletados e analisados sob a metodologia baseada na análise do conteúdo, em dois períodos do ano escolar, através de ferramentas tais como: Mapeamento da comunidade, questionários, entrevistas semi-estruturadas e o diário do professor. A metodologia de validação da informação dos participantes foi implementada para ajudar a melhorar a precisão e validez durante a análise dos dados. As conclusões definem o alcanço da música em Inglês sobre a construção de identidade dos jovens aprendizes, as implicações pedagógicas do estudo descrevem algumas formas nas quais os docentes podem construir um conteúdo curricular relevante através do entendimento e exploração da identidade individual os seus estudantes.

Palavras clave: Identidade; Pedagogia baseada na comunidade; Pedagogia crítica; Recursos de conhecimento; Música como pedagógica. 


\section{Introduction}

$\mathrm{O}$ bserving school students' attitudes and manners, when they are lively sharing in teams during the break time, or attending a lesson in the classroom, has grabbed my attention and has led me to reflect on how life experiences inside and outside the school may affect or model their process of individual identity construction. I also wonder which is the origin of the most common patterns that my students follow to act the way they do, and how their linguistic behavior in the English class is shaped by some cultural trends and art expressions they daily are embedded into.

As part of the reflection upon this relevant topic for my teaching practice, I registered on teachers logs my insights, these written registers guided me to realize that my students' favorite music in English enhances the development of linguistic skills and at the same time models significantly some behavioral aspects.

In 2017 the opportunity to implement a class project came and I invited the students of $10^{\text {th }}$ to join it. "Through problem posing education and questioning the problematic issues in learners' lives, students learn to think critically and develop a critical consciousness which help them to improve their life conditions." (Aliakbari \& Faraji, 2011, p.77).

Bearing in mind the educative context where the present project unfolded, this qualitative study paves the way for English teachers to reflect on the possibilities to establishing curricular connections between classroom practices and students' existing funds of knowledge in their local communities where English teaching takes place.

\section{Literature Review}

\section{Music as a pedagogical tool for English lessons}

Tuning the chords of identity is the metaphor in the title of this paper that unveils salient aspects of youth identity when teachers inquire in the students upon their musical tastes and approach their worlds to give a place and voice at school. Including songs in the classroom as an effective tool for English teaching with young learners, is hugely rewarding due to some songs that can be adapted to introduce new vocabulary and idiomatic expressions in a context.

Hence, music in English should be considered a worthy pedagogical tool to keep students engaged while experiencing an insight into a new culture, without losing motivation towards the learning on L2. Among other different reasons to use songs in the EFL classroom, Schoepp (2001) exposed: 
Songs have become an integral part of our language experience, and if used in coordination with a language lesson they can be of great value. Fortunately, with the expanding prevalence of the Internet and specifically the World Wide Web into both the classrooms and lives of students, access to music and lyrics has been made easier (p.26).

It is the age of YouTube and learners can find practically any song on the website. "Songs contain authentic language, they are easily obtainable, provide vocabulary, grammar and cultural aspects and they are fun for students. Songs can provide valuable speaking, listening and language practice in and out of the classroom." (Lynch, 2012, p. 92). Likewise, teaching English through songs with L2 learners is one of the most motivating sources due to the positive relationship between music and verbal learning; this fact should not be underestimated by teachers of new generations of learners.

Musical genres that students listen to as a social practice and the lyrics they easily enjoy singing, may become pedagogical sources to enhance oral fluency in the English class, while learners get familiar with idiomatic expressions; moreover, "music in English can support the development of a positive self-identity as well as provide confidence, motivation and a sense of group belonging at an early age." (Hallam, 2010, p.273).

In summary, young people get to know themselves as individuals and as groups through cultural activities such as music interaction, nevertheless, choosing a musical genre is an individual experience and invoke emotions and associations which are highly personal.

\section{Youth Identity and music.}

Music has a transformative power for cultures, societies and individuals, it is a universal language and has the ability to transcend culture, age and gender boundaries. It can help people to cope with feelings, emotions and beliefs, even individuals from different contexts, find in music the best way to express and raise their voices to the world.

At present, the concept of identity is seen as a dynamic process rather than a static phenomenon. According to Norton (2000), identity refers to "how a person understands his or her relationship to the world, how that relationship is constructed across time and space, and how the person understands possibilities for the future." (p.5).

In regards with the role of music upon the identity process in a social group, Joseph (2004) maintains, "music plays an integral part in the influence of identity upon members of society, the transformation of an individual or collective identity is determined by the constructs put in place by a society 
made up of social and political standpoints that have developed through time." (p.8).

Otherwise, there is an assumption that our identities, whether group of individual, are not natural facts about us, but "They are things that we construct, fictions, in effect, identities play a significant role in our interaction with others and are part of how we think about ourselves and those around us." (Joseph, 2004, p.6).

Through music interaction, young learners start reflecting critically on lived experiences, at analyzing, exploring and discussing the lyrics of songs or approaching real life experiences of an artist. At school, the role for transformative teachers has to do with uncovering students' worlds while reflecting on their personal experiences and contributing to start processes of personal and social transformation in the communities.

\section{Critical pedagogy}

The idea of associating critical pedagogy with education has mainly been developed by some key scholars such as Freire (1970), Giroux (1992) and McLaren (2003). Critical pedagogy aims at preparing learners who can solve both their own problems and the ones related to the society, as consequence, there is a need for its users and learners to be critical in their learning and use of the language.

This study closely involves students in decisions about learning through inquiries focused on musical experiences in their neighborhoods, as a way to recognize their voices and made them part of the school curriculum. "A democratic curriculum invites young people to shed the passive role of knowledge consumers and assume the active role of meaning makers"(Apple, \& Beane, 2007, p.63).

According to McLaren (2003), critical pedagogy is "a way of thinking about, negotiating, and transforming the relationship among classroom teaching, the production of knowledge, the institutional structures of the school, and the social and material relations of the wider community, society, and nation-state" (p.35).

Under the scope of critical thinking, I was guided to unveil a truth I had not realized before and I managed to understand two realities. Firstly, students' worlds possess valuable elements that, if oriented reflectively, can enrich teaching and learning practices not only for languages, but for other subjects at school. Kumaravadivelu (2003) posits how critical pedagogy takes "seriously the lived experiences that teachers and learners bring to the educational setting." (p.89). His approach lights up curriculum designers of 
educational programs and English teachers that contemplate learners as the subject of their learning.

Secondly, local communities where my students live and grow up, can offer significant information around music exploration concerning youth identity. Since these environments perform and contribute with empirical process of culture transmission and identity construction, they need to be taken into consideration at school settings, within a flexible curriculum that embraces not only theory and policies but also students' needs, skills and interests.

\section{Community Based Pedagogies (CBP)}

In this research, by means of community-based pedagogies, it was feasible to connect school practices and community knowledge environments in one school project where students succeeded to bond their own musical experiences, acquired in real-world settings with the lesson content they were taught at school. Integrating both settings brought about outstanding information that supports and reveals some aspects of youth identity building.

Community-based pedagogies are curriculum and practices that reflect knowledge and appreciation of the communities in which schools are located and students and their families inhabit. It is an asset-based approach that does not ignore the realities of curriculum standards that teachers must address, but emphasizes local knowledge and resources as starting points for teaching and learning (Sharkey \& Clavijo, 2012).

(CBP) helps teachers to recognize that all communities have intrinsic educational and cultural assets and resources that educators can use to enhance meaningful learning opportunities. Interestingly the concept of cultural asset is defined by Gibson (2015) as follows:

In every community that manages to sustain or revive itself over time, there are cultural factors that contribute to the vitality and robustness of the people living there. These factors are shared and creative, which is to say they are cultural, and they are assets that make life valuable, that make life worth living. These cultural assets can be material, immaterial, emotional, or even spiritual (p.112).

Likewise, $\mathrm{CBP}$ is an active critical pedagogy to construct relevant content through local inquiries in the community. The concept of local goes beyond a physical o geographical space, which is just a criterion, it has a sociological understanding in the theory of structuration of Giddens (1991) who states that "because we take human beings as our point of departure (instead of the world), the local is delineated by social integration, face-to-face interaction or interaction between individuals physically co-present."(p.21). 


\section{Methodology}

This case study allowed the exploration of a contemporary real-life phenomenon in the classrooms, related to music in English and youth identity construction. Accordingly, Yin (2003) defines the case study "as an empirical inquiry that investigates a contemporary phenomenon within its real-life context; when the boundaries between phenomenon and context are not clearly evident; and in which multiple sources of evidence are used." (p.23).

The existing case study was developed in the framework of communitybased pedagogy, which made possible to intertwine essential theoretical constructs on identity with rich funds of local knowledge and music in English as a pedagogical tool, to bridge the gap between theory and practice existing in my traditional lessons which had a language approach focused on the development of some skills in isolation.

Case studies are a strategy of inquiry in which the researcher explores in depth a program, event, activity, process or one or more individuals.

If qualitative research were carried out, for instance, on documents, on specific textual corpus or pictures, it would be the people's features and their actions, the productions and situations they develop or have developed, and their existence in those which would be examined to answer the research question in order to continue the analysis on the basis of those features. (Vasilachis de Gialdino,1992, p.43).

Next framework, as explained in the Didactic Unit, see Appendix 1 , guided this exploratory case, to achieve the proposed goals along the development of the project and answer the following research question: How is tenth grade EFL students' identity revealed through local inquiries focused on music in English?

Table 1. Community-based Pedagogy design adapted from Sharkey and Clavijo (2012).

\begin{tabular}{|c|c|}
\hline Research & Teaching \\
\hline $\begin{array}{l}\text { Observation of community practices. } \\
\text { Community scanning /mapping }\end{array}$ & $\begin{array}{l}\text { Understanding learning as a social } \\
\text { practice within a community }\end{array}$ \\
\hline $\begin{array}{l}\text { Investigating community knowledge and } \\
\text { practices } \\
\text { Funds of knowledge }\end{array}$ & $\begin{array}{l}\text { Reflecting and identifying key aspects of } \\
\text { community practices }\end{array}$ \\
\hline $\begin{array}{l}\text { Examining how the curriculum is } \\
\text { constructed and for whom. } \\
\text { Developing research projects that address } \\
\text { community issues in the language } \\
\text { classroom }\end{array}$ & $\begin{array}{l}\text { Establishing possible connections with } \\
\text { the curriculum content } \\
\text { Reflecting upon the implications in their } \\
\text { teaching }\end{array}$ \\
\hline
\end{tabular}


Since this is a qualitative study, "Content Data Analysis" was selected as the methodology to conduct the examination of data collected from the instruments and processes. Lochmiller and Lester (2015) point out that "The data analysis process in qualitative research is often uniquely influenced by the qualitative methodology selected, as well as the theoretical and/or conceptual frameworks that frame the study" (p.40).

\section{Instruments for data collection.}

\section{Mapping the community}

According to Crane and Skinner (2003) "Community mapping is a process that requires strong partnerships; clear goals that everyone in the partnership supports; good communication; commitment to collecting relevant data and analyzing the data for gaps and overlaps."(p.5). Mapping was the initial instrument to start the process of observation, discussion, note-taking, and photographic register for a deep inventory of the students' contexts. Initially, students were told to talk to teenagers or young members in their communities, who exhibited visible similarities and traces of identity with singers or bands of music in English and agreed to take some pictures. After analyzing this inventory of photographic evidence, names of their favorite singers and bands, musical genres and external aspects of music effects on young members of the community were unveiled.

Experiencing mapping their own local surroundings gave my students a factual vision of some members in their local contexts, yet, students could recognize that both interviewers and interviewees had in common similar behavioral features and visible traces, which have been shaped by the impact of the music in English. Also inquiring into some local contexts contributed to raise awareness in the researcher and the group of students, towards the connection that must exist to join community assets and cultural resources with schooling

\section{Video-recorded interviews}

Semi-structured interviews were videotaped as a convenient way to provide detailed information about the social context of each participant in a setting. Scenarios for the video recordings were participants' houses, bedrooms, living rooms and the school yard, all of them within the nearest communities to school. With regards to semi-structured interviews, Fox (2009) maintains that "they are useful when collecting attitudinal information on a large scale, [...] responses can either be tape-recorded or written down by the interviewer" (p.6). Finally, data collected from video recordings were transcribed by the 
researcher and codified in categories and subcategories by using excel charts in OTranscribe online software.

\section{Questionnaires}

In this study, two questionnaires for the students were conducted, the first one, with six questions that sought to find out students' preferences and names of their favorite artists or bands, and their possible reactions when being in touch with these musical genres.

The inquiries for the second questionnaire focused on students' beliefs about the things that model their identity and their perception of music and its effects on them. This questionnaire was integrated to the study in an introductory workshop, after watching a video from Youtube. Ambriz, N Peñuelas,N; Beltrán, A. (2015). It is an inspiring video, related to youth and identity, which offered certain connections with the community project and at the same time encouraged the students to go forward researching into their communities.

\section{Teacher's journal}

The teacher's journal was used to register entries that reported teaching experiences while carrying out the study, as well as class events round the research during regular English lessons. Moreover, students' insights that were commented in class in regards to the learnt experiences while participating in the different stages of this research, were taken into account in this journal.

Keeping notes that described in detail the process I followed with my students to conduct the study, became a useful tool that validated similar findings in data analysis. Gebhard (1999) defines how a teacher journal "can create an opportunity to confront the affective aspects of being a teacher, including what annoys, disconcerts, frustrates, encourages, influences, motivates and inspires us" (p.79). Although writing a diary was time-consuming, the result was a database which allowed me checking the insight that consolidated the categories.

\section{Research context and participants}

This research project was implemented in one of the most traditional public schools of the city, its academic population is 2.897 divided in primary and secondary levels and there are two shifts, afternoon and morning; according to some regulations and policies of the Ministry of Education in two years the school will have only one shift. 
This Community Based study was implemented with the support of twenty-five EFL female tenth-graders, with A1 proficiency level according to the CEFR, these girls are aged fourteen to seventeen, and most of them are interested in learning English.

Students belong to a middle-class stratum and some of them come from different cities because of their parents' jobs, most of these pupils have been studying since primary level in the same institution.

\section{Validation of the information}

With the purpose of validating the data provided by the participants, Member Checking was implemented. It is a technique used by researchers to help improve the validity, accuracy, credibility and transferability "the interpretation and report (or a portion of it) is given to participants in order to check the authenticity of the work, their comments serve as a check on the viability of the interpretation." (Creswell, 1994, p.158).

Informants may also be asked to read any transcripts of dialogues in which they have participated. Here the emphasis should be on whether the informants consider that their words match what they intended. Lincoln and Guba (2009) highlighted that "through research interviews, for member checking, participants gain reflection, self-awareness, finding a voice, obtaining information, and venting repressed emotions." (p.551).

\section{Findings}

The following categories establish key connections with the main constructs exposed in the theoretical framework. Theory was fundamental during the process of shaping the preliminary categories and subcategories that emerged during the analysis. Consequently, they are presented in detail in Table 1.

Table 2. Research question and Categories

\begin{tabular}{|l|l|}
\hline Research Question & Categories \\
\hline How is tenth grade EFL students' & Imitation, a form of social interaction. \\
\cline { 2 - 2 } $\begin{array}{l}\text { identity revealed through local } \\
\text { inquiries focused on music in } \\
\text { English? }\end{array}$ & Admiration, just an emotional impact. \\
\cline { 2 - 2 } & Identification, and seeking self-image. \\
\cline { 2 - 2 } & Music enhances English learning \\
\hline
\end{tabular}




\section{Imitation, a form of social interaction.}

(CBP) oriented this study upon the knowledge of the community through local inquiries in recorded interviews and questionnaires, excerpts from these tools revealed that all the participants in the study admitted having a deep appeal by at least two or three singers of music in English, and also showed their awareness on the effects that continuous music exposure have triggered on them.

"He tratado de imitar a Serj Tankian ya que es un tipo que usa unos looks rockeros geniales, por lo general tiene algún accesorio que me gustaría tener siempre.” (STU, 9, questionnaire, March, 2017).

"El primer cambio físico que realicé fue colorearme un mechón, luego lo pinté de rosa, luego seguí con un tatuaje de calavera que Avril Lavigne precisamente también lo tiene en su brazo izquierdo. Sin duda alguna otro gran cambio que me gustaría hacer por el gusto que ha dejado Lavigne es otro tatuaje de una estrella, en la muñeca." (STU, 4, video recording transcription, May 2017).

Hopper (2010) claims that "Trends that singers exhibit along their performances, impact on teens in different ways, those styles become fashions when teenagers in particular come under the strong influence of the media projection of their favorite singers and bands and start imitating." (p.23). Imitation as a form of social integration in a group, defines an important aspect of youth identity in teens; in fact, photographic registers in the community mapping, displayed patterns in external expressions like fashion styles, shoes, make up, accessories, haircuts, and tattoos that most of the adolescents copy or even imitate from the artists.

\section{Admiration, just an emotional impact.}

In this category the empathy some participants have developed upon particular attitudes, fashion trends or physical features adopted from their musical idols, does not go beyond substantially over the construction of their individual identities; this sense of admiration, neither permeates nor models significant traits on them.

However, outcomes in data analysis evidenced, participants' critical thinking ability in front of topics related to some life philosophies and life styles which are transmitted in the lyrics and videos they have access to. This sense of admiration generates on them uplifting and inspiring feelings towards the character and personality of many musical idols.

"Admiro a Ed Sheeran porque sus canciones de verdad son muy hermosas, él es muy humilde a pesar de tener toda la fama, no pierde 
su sencillez. Uno se pone a mirar aqui en Colombia el reggaeton y todo eso, las canciones degradan a la mujer, en cambio él es diferente, sus canciones son bastante diferentes, dice todo lo que una mujer quiere escuchar de un hombre y eso me llama la atención.” ( STU, 10, video recording transcription, May, 2017).

"Siento admiración por muchos cantantes porque a pesar que la vida de ellos en la niñez fue muy dura, salen adelante, y la letra de las canciones trae enseñanzas."

(STU,10, questionnaire, March 2017).

Having in mind that CBP calls for the understanding of learning as a social practice within a community, it was found that by means of social networks, fans are used to be well acquainted with some social causes addressed by artists in benefit of certain communities or even for the natural environment care. This knowledge allowed the research participants to recognize in their musical idols some human values such as the kindness, humanism, strength and perseverance, on this way admiration goes forward the physical appearance they can observe.

\section{Identification, and seeking self-image.}

It has been shown that music is a source of social cognitive norms that impact the development of adolescents' self-concept. In this vein, Côté, (2009) points out that "Adolescents evaluate their physical attractiveness and self-worth by comparing themselves with music media characters." (p.266). Excerpts that support this category were taken from the video transcriptions in the original language of the recordings.

"Me identifico con la música de Adele, pienso que, en algunas ocasiones, sus gestos, su forma de maquillaje, ella es como muy colorida, más que todo en su música, el tipo de música que me gusta influye en mi como en las demás personas, su ritmo es suave." (STU,1, video recording transcription, May 2017).

"Ifeel identified with Lana del Rey. My favorite type of music is alternative pop. Her vintage style. I like her because she is of other age and she is a little classic."(STU,2, video recording transcription, May 2017).

Hargreaves, Miell and Macdonald (2002) maintain that, music can be used increasingly as a means by which we formulate and express our individual identities. We use it not only to regulate our own everyday moods and behaviors, but also to present ourselves to others in the way we prefer. (p.1). 


\section{Music enhances English learning}

Despite the practice and development of a special skill was not pursued as a research goal, this study can describe ways in which teachers can construct relevant content through identity exploration and local inquiries focused on music in English. Class activities must involve real content, and teachers must be creative at developing their teaching process in order to carry out exciting and challenging tasks focused on real life situations.

"Soy como Hanna Montana (Miley Cyrus) porque la verdad canto como ella, bailo como ella, actúo y bailo como ella baila en los conciertos, en esa serie aprendí a pronunciar bien el Inglés y aprender más muchas palabras y aprender a traducirlas." (STU,03, video recording, May 2017).

Additionally, Schoepp (2001) explains that "Songs have become an integral part of our language experience, and if used in coordination with language lessons they can be of great value." (p.148).

Pedagogical strategies outlined in the didactic unit I designed, allowed students whether to tackle a team work activity, by preparing a TV musical show performance, or to start designing and writing individually a magazine focused on their favorite singer or band. Yet, content-based lessons tap into students interests, when English syllabus relates to the topics that are familiar for them.

\section{Conclusions}

The central purpose for this research project was to unveil salient aspects of youth identity that emerged from students' inquiries about music in English. To reach this objective Critical Pedagogy and Community Based Pedagogy provided the theoretical support and framed this exploratory case study where outcomes obtained showed that:

Local inquiries used as a pedagogical tool, allowed the active participation of each one of the students and favored the integration of rich funds of knowledge in students' families and social contexts with meaningful practices for English learning at school.

Thus, a clear acknowledgement of funds of knowledge in the local communities where students inhabit and are growing up, enabled the researcher to have access to outstanding information related to participants' personal experiences in connection with music and self- identity construction.

Thus, Symbolic interaction that occurs between music celebrities and participants was revealed in three levels clearly defined. Imitation is a higher 
level for participants who exhibited solid and marked traces of identity with a musical idol. The second one, Admiration, is the lowest level of incidence, now that teens are not touched in a significant way and they do not present external evidences of identity with an artist, admiration is manifested just in an emotional stage. The last one is Identification; this intermediate level gathers young people who feel extremely identified with a musical idol but do not present visible features they own just conceptual or attitudinal reasons.

In this research project, students' community assignments conducted through (CBP) and framed on Critical Pedagogy foundations, raised researchers' awareness on the relationship between schooling and families, across multiple dimensions and changing perspectives of neighborhoods and local communities. Drawing on the interaction between school and community, the fourth category focuses on how the funds of knowledge must be understood as key elements to connect school, homes and communities with a curricular design that integrates cultural assets and learning areas in which music and society are intertwined through engaging lectures, insightful interviews, challenging assignments, interesting readings, and of course a lot of musical interaction.

Considering that music in English is one of the most remarkable cultural elements for new learners' generations, it must be considered by curriculum designers and teachers as a powerful pedagogical resource. Most of the stories behind the lyrics, appealing music content, catchy news and biographies of singers and musicians, become useful resources that motivate English learning and increase language practice due to music covers a number of touchy topics that raise students' interests and emotions.

Regrettably, scarce English teaching practices, that privilege the use of grammar rules as the main purpose for English learning, undervalue this new generation of students who are able to develop communicative skills which can embody a convergence of culture and identity.

Classroom projects related to music and songs in English involve the use of real language, improve teaching and learning through a variety of resources to be included in lesson planning. In other words, class activities must involve real content, and teachers must be creative at developing their teaching process in order to carry out exciting and challenging tasks focused on real life situations.

\section{Pedagogical implications}

This community-based study contributes to the educational setting, by integrating local inquiries as a pedagogical tool to look for relevant information in our students' worlds, which most of the time are unknown or misunderstood 
by teachers and curriculum planners. Hence, integrating students' needs and backgrounds with a flexible and negotiated curriculum where they may have a voice and a space in the school context, it may results in students more tolerant, aware and better leaders, who are able to promote deep and analytical thinking not only at school settings but also in their communities.

From my experience in this project, I state that local communities as sources of knowledge, enlighten curriculum designers and teachers with a valid understanding of the cultural assets and funds of knowledge that constitute our students lives and permanently stand their process of identity construction. Moreover, a clear appreciation of students' past experiences, musical tastes, interests, skills and beliefs in regards with music in English, enhance opportunities to propose English lessons with a relevant content and engage learners with meaningful and enjoyable experiences that empower students to succeed at language learning.

In regards with social identity construction, I could evidence in my group of students an improvement in their learning processes and their personal development at expressing freely themselves, sharing life experiences, and recognizing their peers as unique individuals. In sum, it was by means of inquiring in their communities that they recognize the self and the others.

Besides, this research study tackles adolescence as a treasured stage in the human development process for self-identity building, where school practices have a prominent role at addressing opportunities for growing and personal development, as well as cope with the frustrations and challenges that students face during this stage. Yet, for English teachers it is paramount to acknowledge that music as a key component for self and collective identity, permeates students' lives at diverse levels to the extent that the music students identify with, during their early teens often becomes the music that stays with them throughout their life. 


\section{References}

Aliakbari, M. \& Faraji, E. (2011). Basic Principles of Critical Pedagogy. Historical and Social Sciences. Retrieved from Basic principles of critical pedagogy. http://www.ipedr.com/vol17/14-CHHSS\%202011-H00057.pdf

Ambriz, N; Peñuelas,N. (Productors). Beltrán, A (Director). (2015). Nota hit la influencia musical en los jóvenes [Video in Youtube].Mexico: Universidad Autónoma de Baja California.

Apple, M; \& Beane, J. (2007). The Case for Democratic Schools. In Powerful Education. Portsmouth NH: Heinemann, pp.60-72.

Côté, J. (2009). Identity formation and self-development in adolescence. In Lerner, R.M. and Steinberg, L. Hoboken (Ed). Handbook of adolescent psychology, 1, 266. NJ: Wiley.

Crane, K; \& Skinner, B. (2003). Information Brief. Retrieved from http://www. ncset.org/publications/info/NCSETInfoBrief 2.1.pdf

Creswell, J. (1994). Qualitative Inquiry and Research Design Choosing Among Five Traditions. Thousand Oaks, CA: Sage Publications.

Fox, N. (2009). Using Interviews in a research project. The NIHR Research Design Service, p. 6 . Retrieved from https://www.rds-yh.nihr.ac.uk/wpcontent/uploads/2013/05/15 Using-Interviews-2009.pdf

Freire, P. (1970). The pedagogy of the oppressed. (30th ed). Bloomsbury Publishing

Gebhard, J.G. (1999). Reflecting through a teacher journal. In J.G. Gebhard and R.O Oprandy (Ed). Language teaching awareness. New York: Cambridge University Press.

Gibson, R. K. (2015). Party change, social media and the rise of 'citizeninitiated' campaigning. Party Politics, 21(2), 112-5. https://doi. org $/ 10.1177 / 1354068812472575$

Giddens, A. (1991). Modernity and Self-Identity. Cambridge: Polity Press. p.21.

Giroux, H. A. (1992). Border crossings: Cultural workers and the politics of education. New York: Routledge.

Hallam, S. (2010). The power of music: Its impact on the intellectual, social and personal development of children and young people. International Journal of Music Education, 28(3), 269-289. http://dx.doi. org/10.1177/0255761410370658 
Hargreaves, D.J., Miell, D., Macdonald, R. (2002).What are musical identities, and why are they important. Research Gate.1-5 retrieved from

https://www.researchgate.net/publication/252461217 What are musical identities and why are they important

Hopper, L.M (2010). Deferred imitation in children and apes. Psychologist. 23 (4), 23. doi: 10.1002/zoo.21439.

Joseph, J. (2004). Language and Identity National, ethnic, religious. In Alan Davies \&Catherine Elder (eds). The Handbook of Applied Linguistics, p.4. Oxford and New York: Blackwell.

Kumaravadivelu, B. (2003). Critical Language Pedagogy: A Postmethod Perspective. In English Language Teaching. World Englishes, 22 (4), 89. New Haven and London: Yale University Press.

Lincoln, Y.S. \& Guba, E.G. (2009). Naturalistic Inquiry. Newbury Park, CA: Sage Publications.P.551.

Lochmiller, C; Lester, J. (2015). An Introduction to Educational Research: Connecting Methods to Practice. London UK: Sage Publications Inc.P.40.

Lynch, L. (2012). Nine reasons why You Should Use Songs to Teach EFL. Retrieved from www.eslbase.com/teaching/using-songs-to-teach-efl

McLaren, P. (2003). Life in schools: An introduction to critical pedagogy in the foundations of education. White Plains, NY: Longman.

Norton, B. (2000). Identity and language learning: Gender, ethnicity and educational change. Harlow, England: Longman/Pearson Education.

Schoepp, K. (2001). Reasons for using songs in the ESL/EFL classroom. Retrieved from :The Internet TESL Journal,: http://iteslj.org/Articles/ Schoepp-Songs.html

Sharkey, J. \& Clavijo, A. (2012). "Promoting the value of local knowledge in ESL EFL teacher education through community-based field assignments". In Medrado, B. and Carla Reichmann (Eds.). Projetos e praticas na formacao de professors de lingua inglesa. Paraiba: Brasil. Editora Universitaria UFPB.

64 Vasilachis de Gialdino, I. (1992). Métodos cualitativos 1. Argentina: Centro editor de América Latina. P.43.

Yin, R. K. (2003). Case Study Research : Design and Methods (3rd ed.). Thousand Oaks, California: Sage Publications. 


\section{Author}

*Edna Mercedes Bonilla-Salazar holds a Specialization in English Language Teaching and a B.A. in English from Tolima University (Colombia). She is candidate to an English Didactics Master's degree from Universidad del Tolima. In the last two years, she worked on a Community Based research study named: Revealing tenth graders identity through local inquiries focused on music in English, from which the information exposed in the article is part. She has been a teacher for twenty years and managed different types of audiences such as: children, intermediate school students and undergraduate learners. She is currently a part time teacher in the college of Education at Tolima University, as well as full time teacher at Liceo Nacional de Ibagué (Colombia) where she is in charge of the direction of the emphasis Discourse Management and English learning in the same institution. Her research interests are the sociocultural and intercultural dimensions of English language learning and teaching.

ORCID: https://orcid.org/0000-0002-7938-5710 
Apendix 1

\begin{tabular}{|c|c|c|c|c|}
\hline \multicolumn{5}{|c|}{$\begin{array}{l}\text { Didactic Unit } \\
\text { In what ways do community inquires offe } \\
\text { ways music in English permeates youth id }\end{array}$} \\
\hline \multicolumn{5}{|c|}{ Teacher: Edna Mercedes Bonilla Salazar } \\
\hline \multicolumn{5}{|c|}{$\begin{array}{l}\text { General Objective: To approach student's context to inquire about the incidence of music in English upon the } \\
\text { construction of identity in local communities. }\end{array}$} \\
\hline \multicolumn{5}{|c|}{$\begin{array}{l}\text { Standards: } \\
\text { 1. Participo en conversociones en los que puedo explicar mis opiniones e ideos sobre temos generoles personales y } \\
\text { obstroctos. } \\
\text { 2.1dentifico los valores de otros culturos y eso me permite construir mi interpretoción de su identidad } \\
\text { 3. En un texto identifico los elementos que me permiten oprecior los valores de lo culturo ongloporlonte. } \\
\text { 4.Opino sobre los estilos de vido de lo gente de otros culturos opoyóndome en textos escritos y oroles previamente } \\
\text { estudiados }\end{array}$} \\
\hline Date & Activity & Objective & Community Sources & Outcomes \\
\hline \multirow[t]{5}{*}{$\begin{array}{l}\text { From march } \\
6^{\text {th t }} \text { to march } \\
31^{2}\end{array}$} & $\begin{array}{l}\text { Observation of } \\
\text { community } \\
\text { practices } \\
\text { Consolidating } \\
\text { questions and } \\
\text { objectives. }\end{array}$ & $\begin{array}{l}\text { Outlining the cultural } \\
\text { features in young } \\
\text { members of the } \\
\text { community. }\end{array}$ & Funds of knowledge & $\begin{array}{l}\text { Music and Identity } \\
\text { landscape }\end{array}$ \\
\hline & $\begin{array}{l}\text { Keeping the } \\
\text { teachers' journal }\end{array}$ & \multirow[t]{4}{*}{$\begin{array}{l}\text { Mapping the students' } \\
\text { social and familiar } \\
\text { contexts. }\end{array}$} & $\begin{array}{l}\text { School, and } \\
\text { neighborhoods }\end{array}$ & $\begin{array}{l}\text { Cultural features to } \\
\text { focus on the } \\
\text { mapping. }\end{array}$ \\
\hline & $\begin{array}{l}\text { Selecting the } \\
\text { assets to work } \\
\text { with in the } \\
\text { communities. }\end{array}$ & & Family context & \\
\hline & $\begin{array}{l}\text { Methodological } \\
\text { design of } \\
\text { instruments } \\
\text { Mapping }\end{array}$ & & $\begin{array}{l}\text {-Group Dancing } \\
\text { Competition -Rehearsals } \\
\text { and Final Performance }\end{array}$ & \\
\hline & $\begin{array}{l}\text { Students take } \\
\text { some pictures of } \\
\text { people in their } \\
\text { communities and } \\
\text { identify potential } \\
\text { participants. }\end{array}$ & & & $\begin{array}{l}\text { Photos of young } \\
\text { members in the } \\
\text { community }\end{array}$ \\
\hline \multirow[t]{3}{*}{$\begin{array}{l}\text { From April } \\
3^{\text {dd }} \text { to April } \\
29 t h\end{array}$} & $\begin{array}{l}\text { Investigating } \\
\text { Community } \\
\text { Knowledge and } \\
\text { Practices. } \\
\text { Instruments } \\
\text { design }\end{array}$ & $\begin{array}{l}\text { Identifying through an } \\
\text { interview key aspects of } \\
\text { the incidence of music in } \\
\text { English in the } \\
\text { construction of } \\
\text { Individual identity. }\end{array}$ & \multirow[t]{3}{*}{$\begin{array}{l}\text { School students } \\
\text { young members in the } \\
\text { communities and } \\
\text { students' friends } \\
11 \text { videos and } 1 \text { podcast }\end{array}$} & $\begin{array}{l}\text { Inquiry questions for } \\
\text { participants. }\end{array}$ \\
\hline & $\begin{array}{l}\text { Inquiry plan } \\
\text { Semi structured } \\
\text { interviews and } \\
\text { video recordings }\end{array}$ & $\begin{array}{l}\text { Analyzing the video } \\
\text { recordings of the } \\
\text { students and finding } \\
\text { commonalities } \\
\text { throughout the answers }\end{array}$ & & $\begin{array}{l}\text { Video recordings and } \\
\text { semi structured } \\
\text { interview. }\end{array}$ \\
\hline & $\begin{array}{l}\text { Keeping the } \\
\text { teacher's journal }\end{array}$ & & & $\begin{array}{l}\text { Charts with } \\
\text { Transcriptions from } \\
\text { the videos }\end{array}$ \\
\hline
\end{tabular}




\begin{tabular}{|c|c|c|c|c|}
\hline \multirow[t]{2}{*}{$\begin{array}{l}\text { May } 1^{\text {tit }} \text { to } \\
\text { May } 19 \text { th }\end{array}$} & $\begin{array}{l}\text { To raise } \\
\text { awareness on the } \\
\text { topic. } \\
\text { Students watched } \\
\text { and analyzed a } \\
\text { video from } \\
\text { Youtube related } \\
\text { to music and } \\
\text { Identity in young } \\
\text { people. }\end{array}$ & $\begin{array}{l}\text { Inquiring about students' } \\
\text { music preferences and } \\
\text { reasons to admire their } \\
\text { favorite singers }\end{array}$ & & $\begin{array}{l}\text { Data from Students' } \\
\text { insights and opinions } \\
\text { in the } \\
\text { Questionnaire }\end{array}$ \\
\hline & $\begin{array}{l}\text { Data collection } \\
\text { and analysis }\end{array}$ & $\begin{array}{l}\text { Analyzing students } \\
\text { voices }\end{array}$ & & $\begin{array}{l}\text { Data Analysis and } \\
\text { construction of the } \\
\text { categories }\end{array}$ \\
\hline \multirow[t]{2}{*}{$\begin{array}{l}\text { May } 20^{\text {th }} \text { to } \\
\text { June } 1^{\text {st }}\end{array}$} & $\begin{array}{l}\text { To determine } \\
\text { what standards } \\
\text { and competences } \\
\text { from the National } \\
\text { curriculum are } \\
\text { suitable to } \\
\text { support the } \\
\text { project. }\end{array}$ & $\begin{array}{l}\text { Establishing possible } \\
\text { connections with the } \\
\text { curriculum content. }\end{array}$ & \multirow[t]{2}{*}{$\begin{array}{l}\text { Video recording } \\
\text { Transcriptions }\end{array}$} & \\
\hline & $\begin{array}{l}\text { Examining how } \\
\text { curriculum is } \\
\text { constructed }\end{array}$ & $\begin{array}{l}\text { Understanding learning } \\
\text { as a social practice } \\
\text { within a community. }\end{array}$ & & $\begin{array}{l}\text { Curricular } \\
\text { connections with } \\
\text { community issues. }\end{array}$ \\
\hline \multirow[t]{2}{*}{$\begin{array}{l}\text { From June } \\
5^{\text {th }} \text { to June } \\
23^{\text {rd }}\end{array}$} & Data collection & $\begin{array}{l}\text { Reflecting upon the } \\
\text { implication of music } \\
\text { incidences (effects) in } \\
\text { young learners teaching. }\end{array}$ & & \\
\hline & $\begin{array}{l}\text { Organizing Data } \\
\text { from the different } \\
\text { instruments }\end{array}$ & $\begin{array}{l}\text { Organizing and analyzing } \\
\text { the information } \\
\text { collected to find } \\
\text { commonalities }\end{array}$ & $\begin{array}{l}\text { "Juegos interclases" } \\
\text { Dancing performance } \\
\text { As a cultural source }\end{array}$ & \\
\hline \multirow[t]{4}{*}{ August } & $\begin{array}{l}\text { Defining students' } \\
\text { artifacts }\end{array}$ & & \multirow[t]{4}{*}{$\begin{array}{l}\text { English Day as a cultural } \\
\text { resource }\end{array}$} & Students artifacts \\
\hline & \multirow{3}{*}{$\begin{array}{l}\text { Meeting the } \\
\text { findings and } \\
\text { Reflecting upon } \\
\text { the conclusions } \\
\text { and pedagogical } \\
\text { implications of } \\
\text { the research }\end{array}$} & & & $\begin{array}{l}\text { Students } \\
\text { performance. }\end{array}$ \\
\hline & & & & $\begin{array}{l}\text { Licenal music awards. } \\
\text { Oral performance }\end{array}$ \\
\hline & & & & $\begin{array}{l}15 \text { written Magazines } \\
\text { on Identity }\end{array}$ \\
\hline September & Member Checking & & Eleven graders at school & $\begin{array}{l}\text { Validation of the } \\
\text { information. }\end{array}$ \\
\hline
\end{tabular}

